\title{
A new species of Pseudoniphargus (Crustacea, Amphipoda) from subterranean water of northeastern Morocco: Historical biogeography and evolutionary aspects
}

\author{
A. Fakher el Abiari' ${ }^{1}$, Z. Oulbaz ${ }^{1}$, M. Messouli ${ }^{1}$ \& N. Coineau ${ }^{2}$ \\ 'Université de Marrakech, Faculté des Sciences Semlalia, Laboratoire d'Hydrobiologie, BP SI5, \\ Marrakech, Maroc, e-mail: fssm.bio@cybernet.net.ma; ${ }^{2}$ Université P. et M. Curie, Observatoire \\ Océanologique de Banyuls, UMR CNRS 7628, Laboratóire Arago, 66650 Banyuls-sur-Mer, France, \\ e-mail: n.coineau@arago.obs-banyuls.fr (corresponding author)
}

Keywords: Systematics, historical biogeography, Crustacea, groundwater Amphipoda, Pseudoniphargus, Morocco

\begin{abstract}
A new species of Pseudoniphargus, $P$. longiflagellum (Crustacea, Amphipoda) is described from subterranean fresh water of the Rifian region of Morocco. This species is closely related to the group $P$, ruffol-P. longipes, which shares several apomorphic characters. The two-step model of colonization and evolution provides an understanding of the origin and the age of this stygobiont. $P$. longiflagellum is derived from marine ancestors that lived in the coastal groundwater of the Tethyan South-Rifian channel during the Miocene Tortonian period. The regression of this corridor during the late Tortonian period or at the beginning of the Messinian period may have played a major role in the evolutionary history through vicariance.
\end{abstract}

\section{Contents}

Introduction

Systematic description

162

Historical bìogeography: origin, age

Acknowledgements

References

\section{Introduction}

Since the discovery of the first Moroccan representative of the genus Pseudoniphargus (Crustacea: Amphipoda), three additional species have been described from subterranean water of northeastern Morocco (Boutin \& Coineau, 1988; Coineau \& Boutin, 1996).

The four Pseudoniphargus species presently known from Morocco are: $P$. maroccanus Boutin
\& Coineau, 1988, P. romanorum Coineau \& Boutin, 1996, $P$. ruffoi Coineau \& Boutin, 1996, and $P$. longipes Coineau \& Boutin, 1996.

During an ongoing biospeleological investigation of groundwater in northern Morocco (A. Fakher el Abiari, M. Messouli, Z. Oulbaz \& M. Yacoubi), some of us collected species of Pseudoniphargus in 18 stations out of 55 sampled wells and springs. In addition to $P$. ruffoi, four of five species are unknown to science. One of them is described below.

Therefore, the genus Pseudoniphargus seems to be diversified in northern Morocco as in other Mediterranean regions. Many species have been reported from subterranean water of Spain (Stock, 1980; Notenboom, 1986, 1987 a \& b; Pretus, 1988, 1990; Jaume, 1991), Sicily (Karaman \& Ruffo, 1989), Italy, Yugoslavia, Algeria and Tunisia (Stock, 1980; Karaman, 1978; Holsinger, 1994). The genus is also known from the Canary Islands (Stock, 1980, 1988; Sánchez, 1990, 1991), Azores and Madeira (Dahl, 1958; Stock, 1980; Stock \& Abreu, 1992) and from Bermuda (Stock et al., 1986).

The phylogenetic relationships and biogeography within the genus have been presented by Stock (1980) and Notenboom (1988). In Morocco, phylogenetic relationships, age, and origin of the species have also been considered (Boutin \& Coineau, 1988; Coineau \& Boutin, 1996).

In the present paper, the description of a new species is given together with remarks on phylogenetic and biogeographic aspects. 
Systematic description

Pseudoniphargus longiflagellum n. sp.

(Figs. 1-5)

Material - One male (holotype) and six juveniles, Jmaa Oulad Aissa; six males and females (one female allotype and five paratypes) and 14 juveniles, Guermelloul; wells (A. Fakher el Abiari, M. Messouli, Z. Oulbaz and M.Yacoubi-Khebiza coll.).

Diagnosis. - Interstitial subterranean species characterized by the following combination of traits: long antenna 1 with more than 30 segments on flagellum, elongate first segment of antenna 2, wide carpus of gnathopod 2, high number of spine groups on pereiopods 6 and 7 propodus and on uropod 3 exopod, and short exopod of uropod 2. Closely related to $P_{x}$ ruffoi, especially in the proportions of uropod 3 with a relatively short peduncle.

Description. - Adult male holotype: $5.90 \mathrm{~mm}$ (Fig. 1); female allotype: $6.53 \mathrm{~mm}$; paratypes: from 6.17 to $6.65 \mathrm{~mm}$. Lateral cephalon regular and straight, anteroventral sinus present (Fig. 1).

Antenna 1 (Fig. 1) very long, slightly longer than body or as long as body in males, slightly shorter as body in females. Peduncle slender with elongate articles, first of which with two spines; flagellum 33-41-segmented (male) and 32-33-segmented (females); accessory flagellum longer than the first flagellar segment, reaching $1 / 2$ of the following segment length.

Antenna 2 (Figs. 1,2C) reaching about $1 / 3$ of first antenna length; flagellum 12-13-segmented in males, 9-11-segmented in females.

Labrum (Fig. 2A) wider than high; round margin provided with thin setae.

Mandible (Figs. 2F, G ): Pars incisiva with 5 teeth, lacinia mobilis provided with 4-5 teeth and a plumose seta in left.mandible, and with a bilobous processus, the margin of which crenulated, in right mandible; processus incisivus accessorius with 3 (right) - 4 (left) barbed setae; palp triarticulated: 3-4 setae on segment 2, segment 3 with 6-7 D-sickleshaped setae, 3 long distal and 2 median setae.

Lower lip (Fig. 2H): inner lobes narrow, long and narrow lateral processes.

Maxilla 1 (Fig. 2D): male holotype: seven strong spines on outer lobe, 2 plumose setae on inner base lobe, this lobe $1 / 2$ length of outer one; bisegmented palp with distal thin setae.

Maxilla 2 (Fig. 2E): male holotype: inner lobe with 12 long setae and inner margin delicately ciliated; outer lobe with 13 distal setae and 2 subdistal plumose setae.

Maxillipede (Fig. 2B): elongate; inner lobe provided with two distal lanceolate setae, two long bare setae, one smaller plumose seta and one setule in male holotype; inner margin without setule. Outer lobe reaching $3 / 4$ second palp segment length, armed with 10 lanceolate setae, two strong barbed setae and small lower thin ciliated setae; lower part of the lobes with two setae. Palp: second segment long, slightly larger in middle part, with numerous thin setae scattered all over the inner margin; segment 3 long and narrow with long subdistal and distal setae; claw of dactylus longer than dactylus.

Gnathopod 1 (Fig. 3). Coxal plate higher than wide, convex anterior margin with 3 to 4 minute setae, long setae on basis; propodus longer than carpus; propodus: 3 bicuspid spines +2 very small spines on palmar angle; palmar margin slightly curved, claw longer than palm.

Gnathopod 2 (Fig. 3). Coxal plate similar to that of gnathopod 1, with $3+3$ to $4+3$ setae on margin; basis wider from median to apex region with 5 setae on posterior margin; propodus and carpus wide; 3 long spines at palmar angle; short palm with a lamina and small setules; claw shorter than dactylus.

Pereiopod 3 (Fig. 4A). Coxal plate narrow and high with 3 to 6 setae on margin; basis with 4 long and 1 short setae on posterior margin, 3 long +2 short setae on anterior margin.

Pereiopod 4 (Fig. 4B). Coxal plate higher as wide with 6-7 setules on margin and posterior excavation marked, not very deep; posterior margin of basis with 4 long setae, one on anterior margin; unguis slightly shorter than dactylus.

Pereiopods 6-7 (Figs. 4C, D). Basis wide, with convex margins; posterodistal lobe slightly marked on $\mathrm{P}$, propodus longer than carpus with 4-5 groups of spines on margins.

Epimeral plates: The first one exhibits 2-4 setae; plates 2 and 3 with 3 spines on ventral margin and 2-3 setae on porterior one.

Pleopods. Two retinacula on peduncle, inner rami with 8-9 to 7-9 and 6-8 articles from pleopods 1 to 


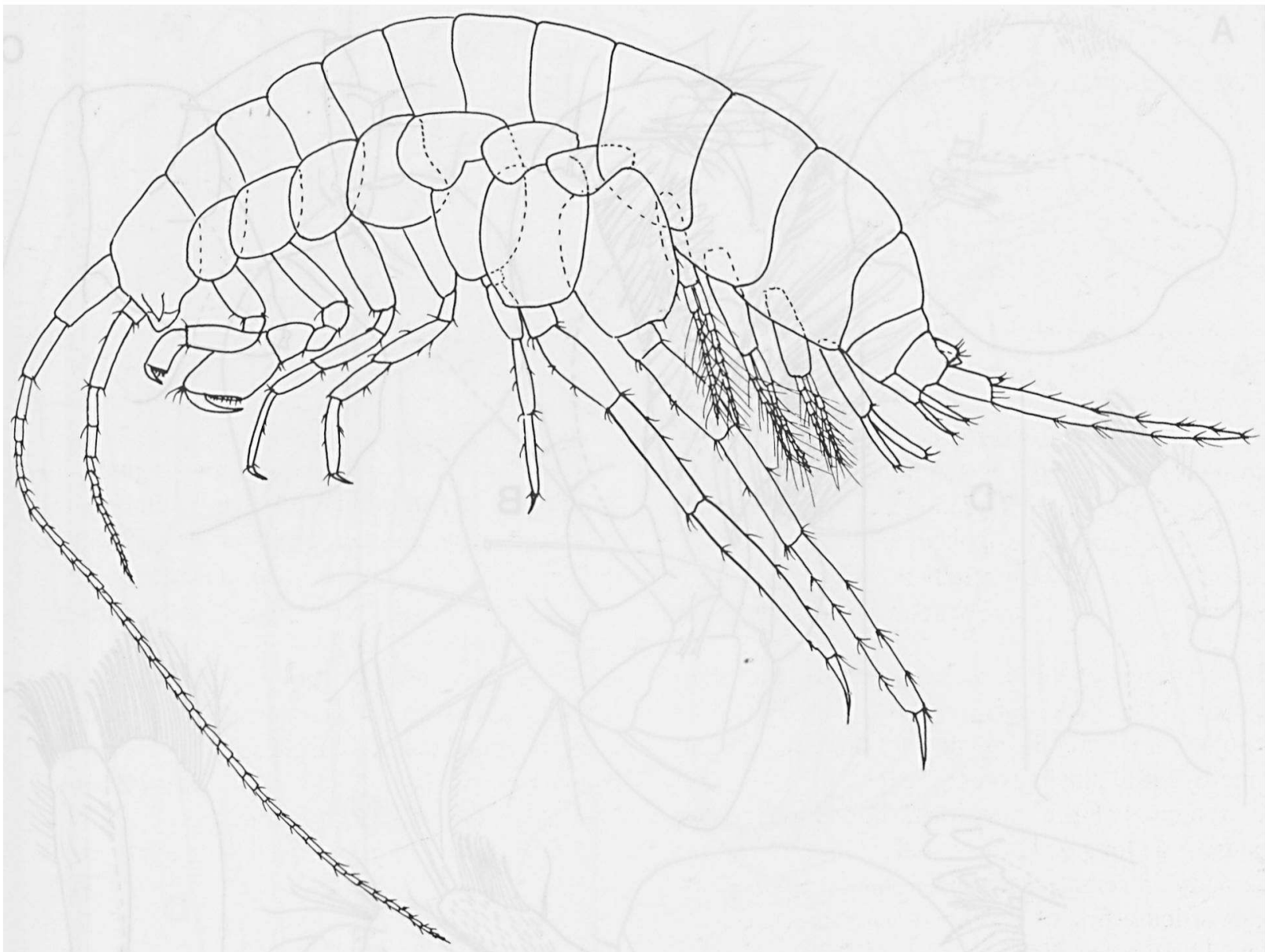

Fig. 1. Habitus of Pseudoniphargus longiflagellum n. sp., male holotype: $5.9 \mathrm{~mm}$.

3; outer rami with 10-11 to $9-10$ and 8-9 articles from pleopods 1 to 3 .

Uropod 1 (Fig. 5A). Long and strong peduncle with basoventral spine, and dorsal row of 5-6 spines and 2-4 medial spines; strong and long distomedial spine; endopod with one marginal and 5 distal spines; exopod slightly shorter than endopod, with 5 distal spines.

Uropod 2 (Fig. 5B). Peduncle short, with one dorsal and 3 distal spines; exopod clearly shorter than endopod with $0-1$ marginal and 5 distal spines. One to 3 marginal spines on endopod.

Uropod 3 (Fig. 5C). Peduncle slightly elongate, about $2 / 3$ as wide as long; 1 spine on margin; endopod with one terminal spine (in one case, 2 distal spines) and 1 distal seta (not constant). Exopod 11 times as long as wide, margins with 7-11 groups of spines, 5-7 distal spines slightly shorter than marginal spines.

Telson (Fig. 5D). Wider than long, with very shallow distal emargination and 3 distal spines on each side.

Derivatio nominis. - The specific name refers to the high number of the antenna 1 segments resulting in a very long flagellum, which distinguishes this species from all other known species of the genus.

Remarks. - Pseudoniphargus longiflagellum n. sp. is easily distinguished from the other species by the characters given in the diagnosis. It is closely allied with $P$. ruffoi; it differs from the latter by the spine on uropod 3 peduncle and only one distal 


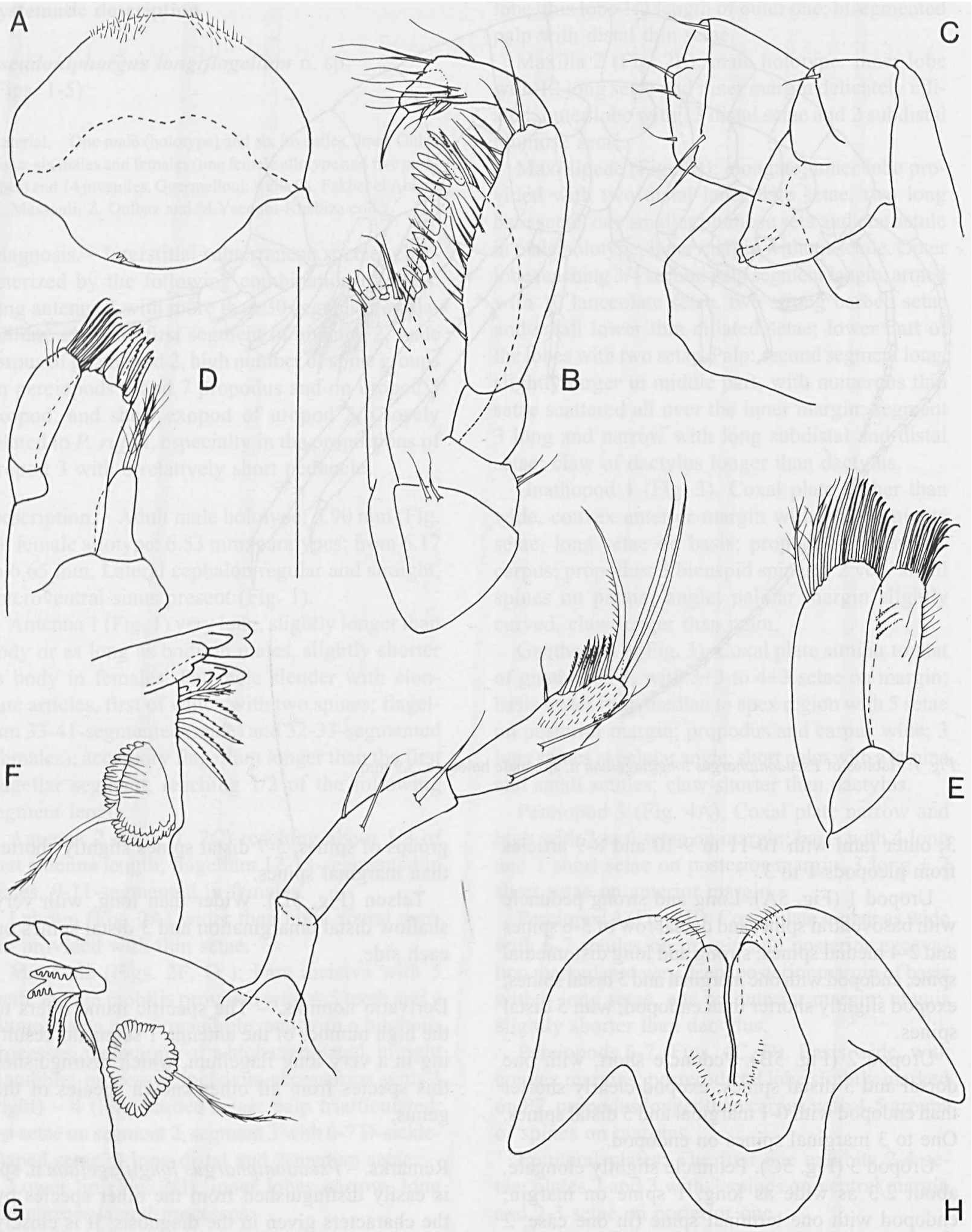

Fig. 2. Pseudoniphargus longiflagellum n. sp., male holotype: A, upper lip; B, maxillipede; C, gland cone of second antenna; D, maxilla 1; E, maxilla 2; F, left mandible; G, right mandible; $\mathrm{H}$, lower lip. Scale bar: $0.3 \mathrm{~mm}$. 

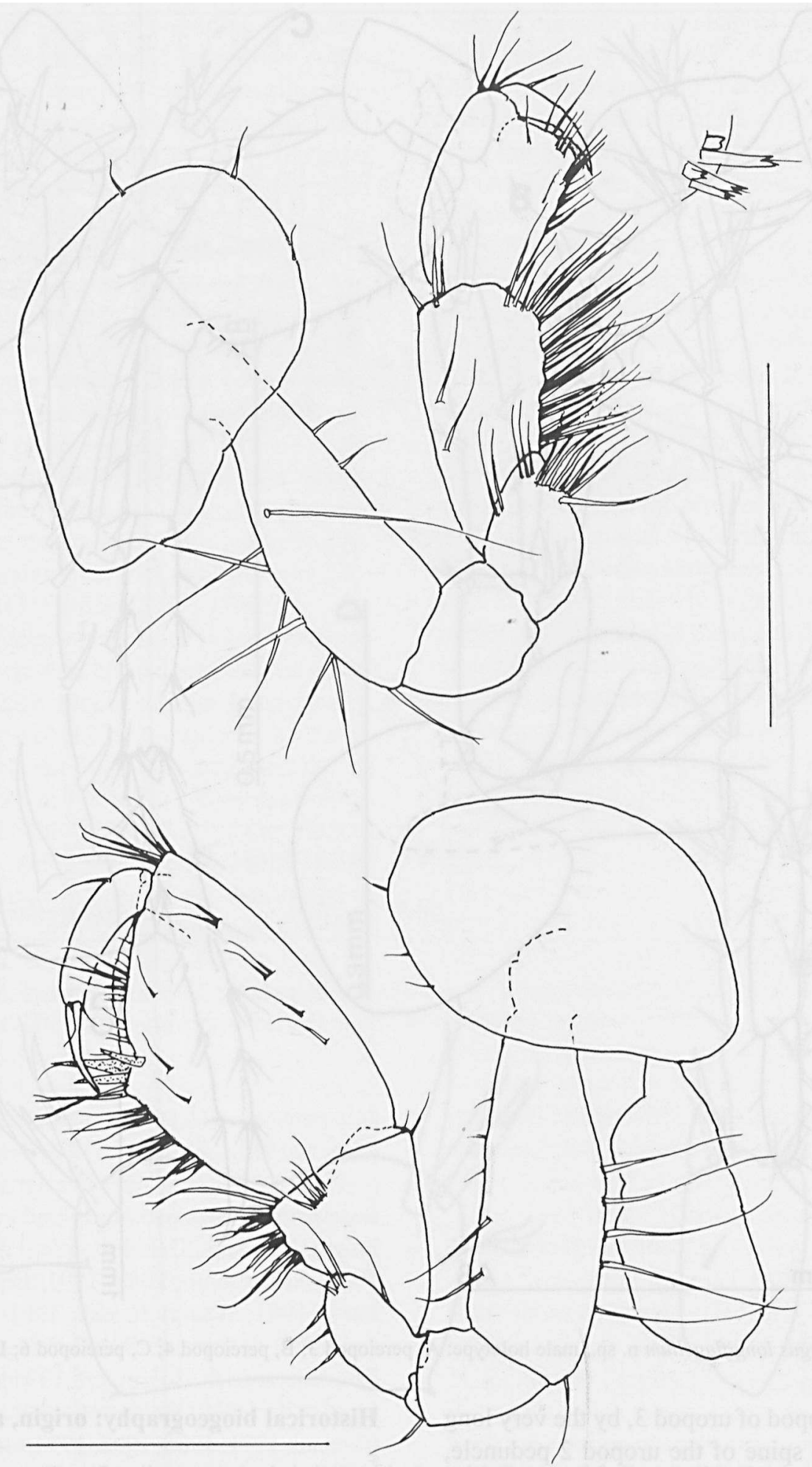

Fig. 3. Pseudoniphargus longiflagellum n. sp., male holotype: Gnathopod 1 and spines of the palmar angle (above); gnathopod 2 (below). Scale bar: $0.5 \mathrm{~mm}$. 


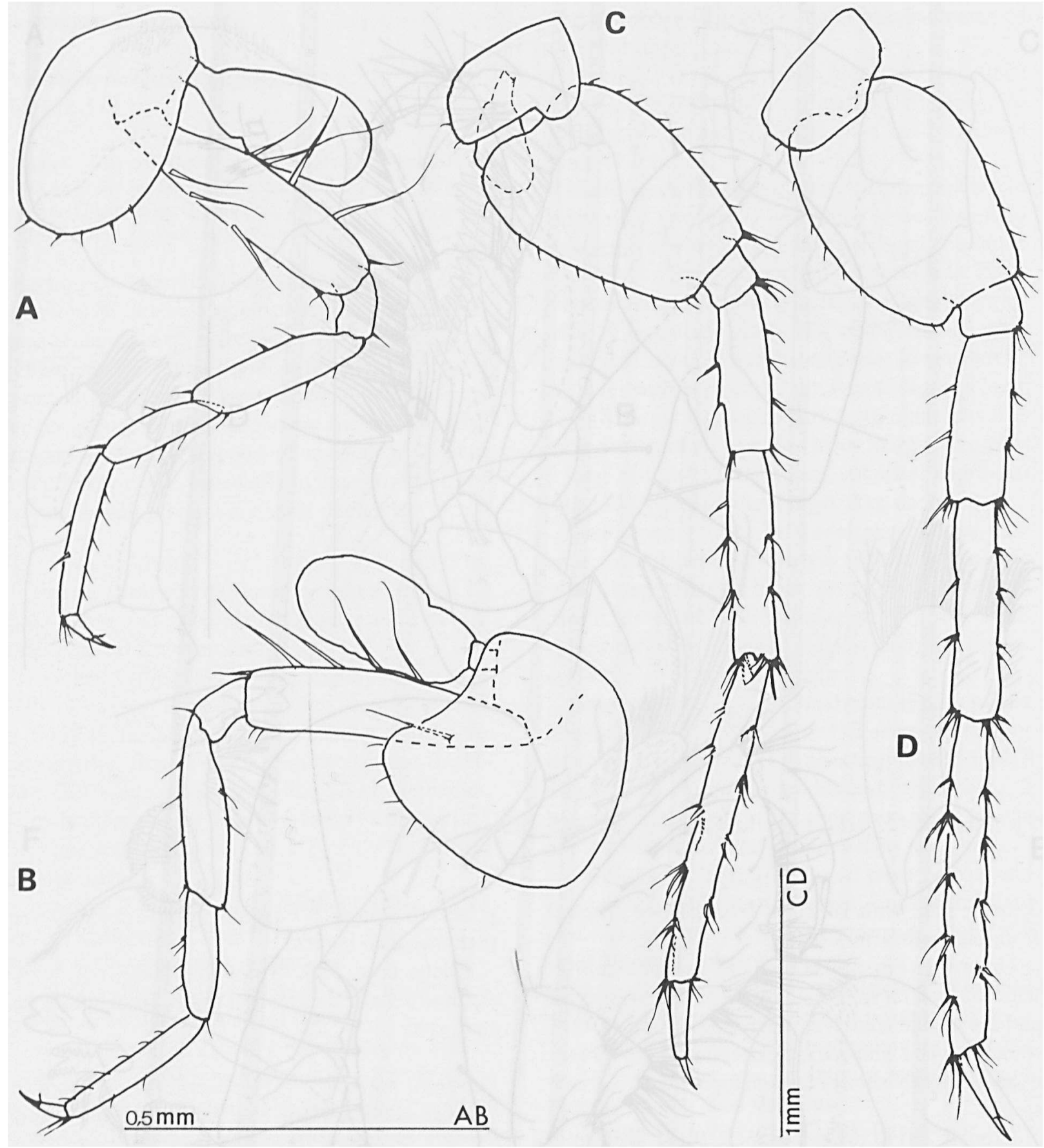

Fig. 4. Pseudoniphargus longiflagellum n. sp., male holotype: A, pereiopod 3; B, pereiopod 4; C, pereiopod 6; D, pereiopod 7.

spine on the endopod of uropod 3, by the very long and strong distal spine of the uropod 2 peduncle, and by the absence of spine on uropod 1 exopod. The telson is similar to that of $P$. longipes, though slightly shorter. The propodus of the pereiopods 6 and 7 are less elongate than in P. ruffoi.

\section{Historical biogeography: origin, age}

The phylogenetic relationships within Iberian species (Notenboom, 1988; Boutin \& Coineau, 1988; Stock, 1980) and Moroccan species (Coineau \& Boutin, 1996) of the genus Pseudoniphargus have 

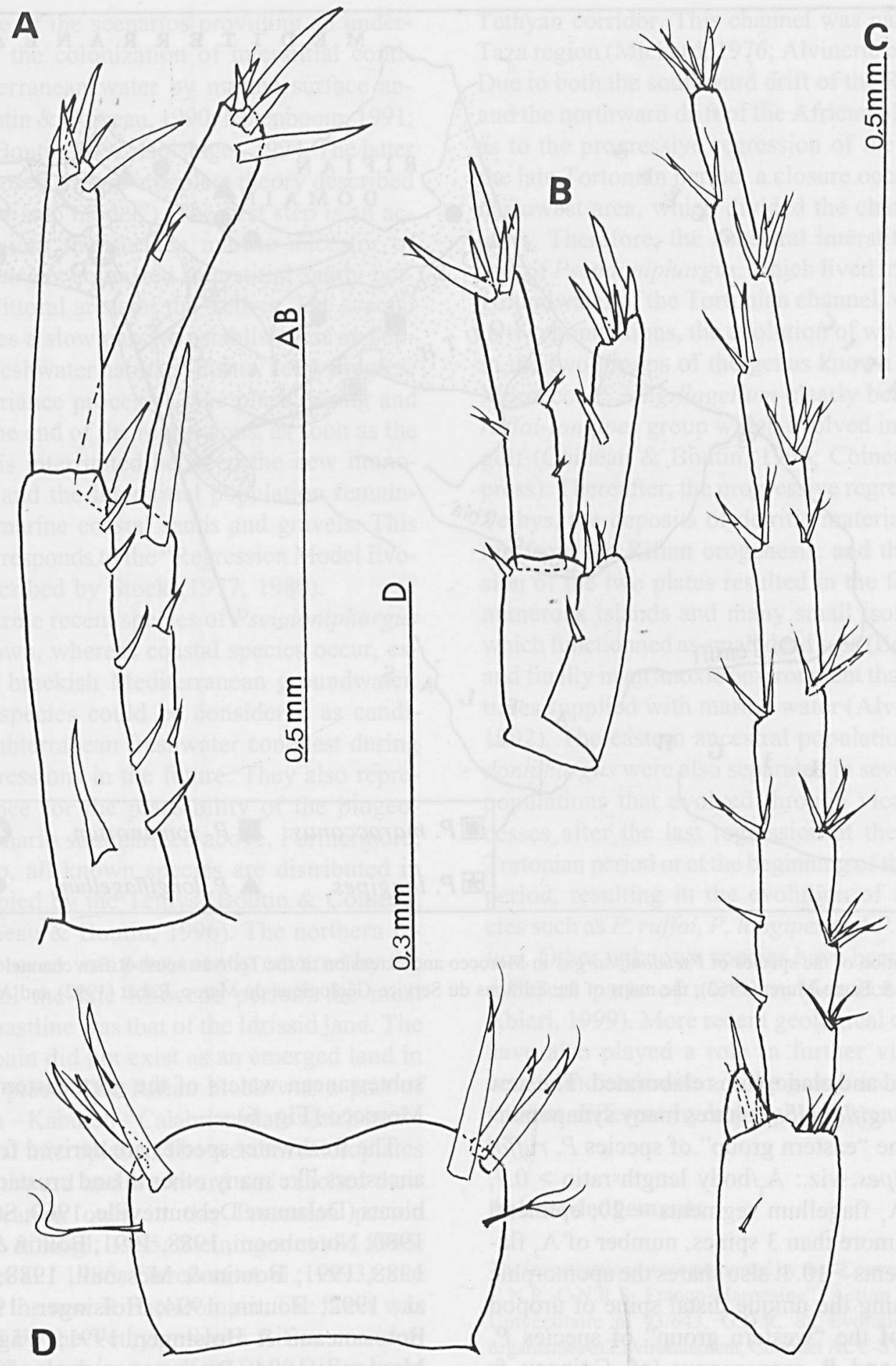

皇
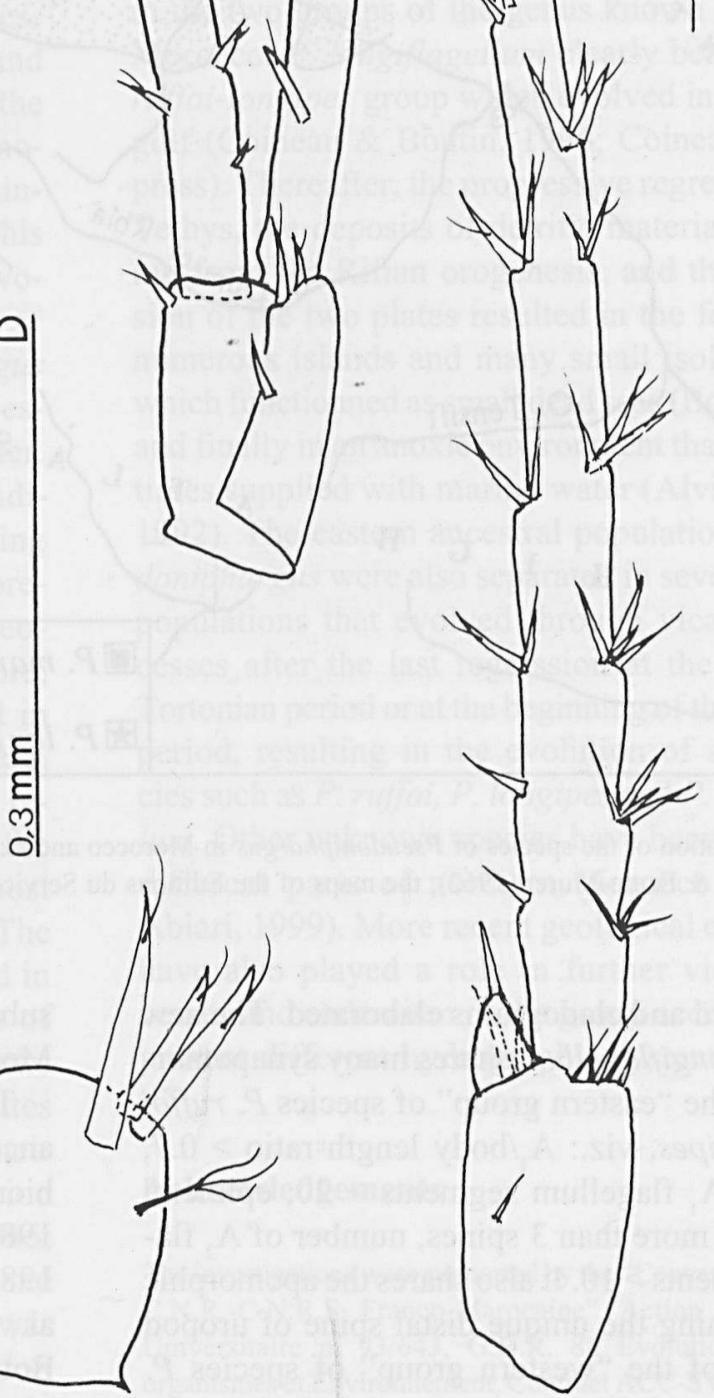

Fig. 5. Pseudoniphargus longiflagellum $\mathrm{n}$. sp., male holotype: A, uropod 1; B, uropod 2; C, uropod 3; D, telson. 


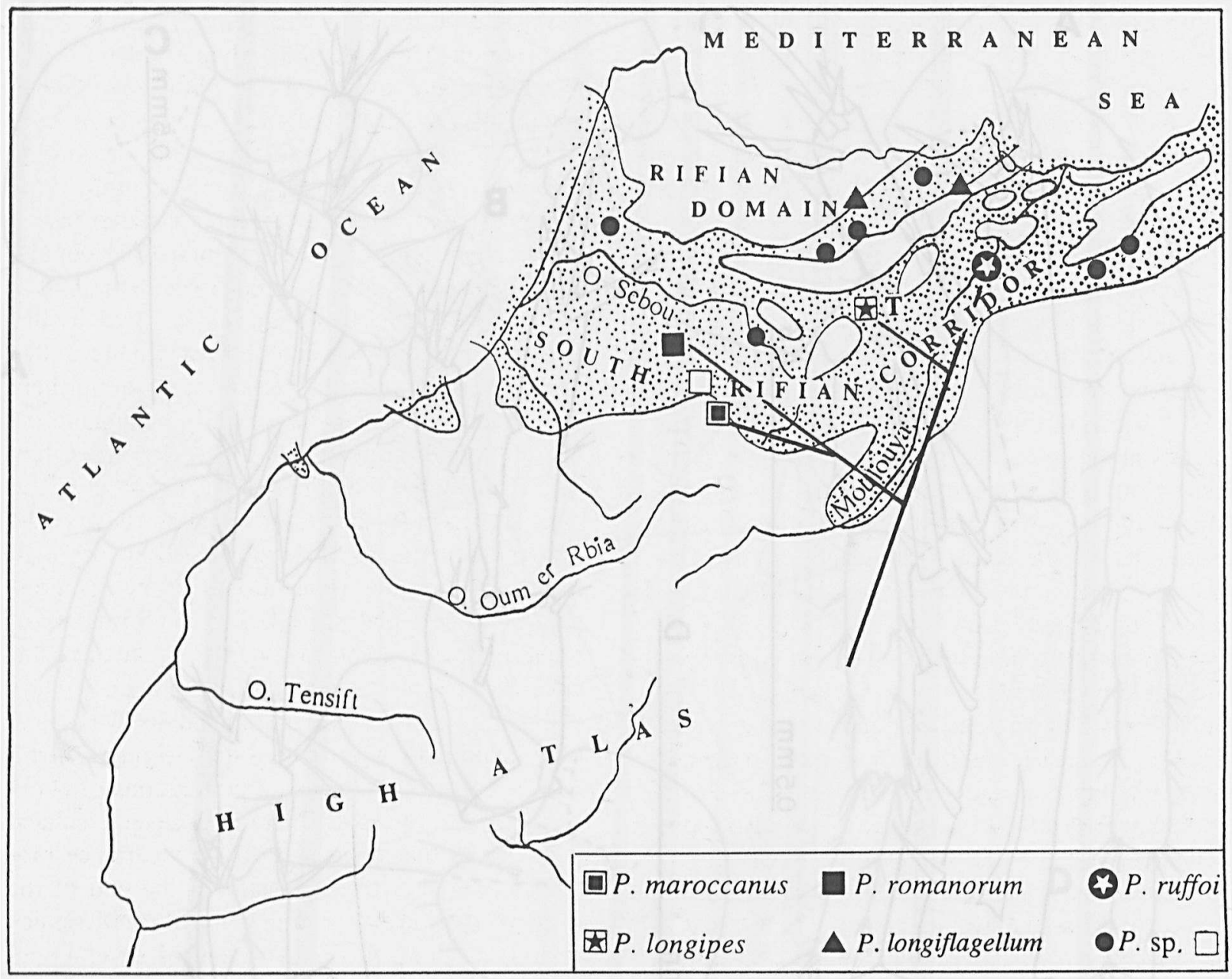

Fig. 6. Distribution of the species of Pseudoniphargus in Morocco and extension of the Tethyan south-Rifian channel (dotted area), after Choubert \& Faure-Muret (1962), the maps of the Editions du Service Géologique du Maroc, Rabat (1992) and Alvinerie et al. (1992).

been exposed and cladograms elaborated. The new species $P$. longiflagellum shares many synapomorphies with the "eastern group" of species $P$. ruffoi and $P$. longipes, viz.: $\mathrm{A}_{1} /$ body length ratio $>0.7$, number of $A_{1}$ flagellum segments $>20$, epimeral plate 3 with more than 3 spines, number of $A_{2}$ flagellum segments $>10$. It also shares the apomorphic trait concerning the unique distal spine of uropod 3 endopod of the "western group" of species $P$. romanorum and $P$. maroccanus (cf. Coineau \& Boutin, 1996), but uropod spines are not very short as in $P$. ruffoi, and they are shorter than in other Moroccan species. The new species belongs to the monophyletic group of the Moroccan species.

Pseudoniphargus longiflagellum $\mathrm{n}$. sp. occurs in subterranean waters of the northeastern region of Morocco (Fig. 6).

The freshwater species are derived from marine ancestors like many other inland crustacean stygobionts (Delamare Deboutteville, 1960; Stock, 1977, 1980; Notenboom, 1988, 1991; Boutin \& Coineau, 1988, 1991; Boutin \& Messouli, 1988; Boutin et al., 1992; Boutin, 1994; Holsinger, 1986, 1994; Botosaneanu \& Holsinger, 1991; Wägele, 1990; Messouli, 1994; Boulanouar et al., 1995, 1997; Coineau, 1971, 1986, 1992, 1994; Coineau \& Boutin, 1996; Yacoubi-Khebiza et al., 1997). Extant representatives of the genus still occur in brackish water of marine sandy beaches.

The "two-step model" of colonization and evo- 
lution is one of the scenarios providing an understanding of the colonization of interstitial continental subterranean water by marine surface ancestors (Boutin \& Coineau, 1990; Notenboom, 1991; Coineau \& Boutin, 1992; Holsinger, 1994. The latter author proposed a more complete theory described as the "three-step model"). The first step is an active dispersion: the surface marine ancestor of $P$ seudoniphargus colonized interstitial sandy bottom in the littoral areas of the Tethys. The second step involves a slow passive establishment in subterranean freshwater habitats, due to Tethys regressions. Vicariance processes take place during and mainly at the end of the regressions, as soon as the gene flow is interrupted between the new limnostygobiont and the interstitial population remaining in the marine coastal sands and gravels. This last step corresponds to the "Regression Model Evolution" described by Stock $(1977,1980)$.

Fully marine recent species of Pseudoniphargus are not known, whereas coastal species occur, especially in brackish Mediterranean groundwater. The latter species could be considered as candidates for subterranean freshwater conquest during further regressions in the future. They also represent evidence for the plausibility of the biogeographic scenario summarized above. Furthermore, in Morocco, all known species are distributed in areas occupied by the Tethys (Boutin \& Coineau, 1988; Coineau \& Boutin, 1996). The northern region of Morocco was permanently covered by the Tethys until the late Miocene period: the most northern coastline was that of the Idrissid land. The Rifian domain did not exist as an emerged land in its present place. The Rifian block was a part of the Alboran-Kabilian-Calabrian plate which broke up in several microplates. The western microplates drifted southward and westward and reached their present location only in the Tortonian period (Steininger \& Rögl, 1985; Steininger et al., 1985; Dercourt et al., 1985; Dercourt et al., 1993) and constituted the new Rifian Domain. The latter was surrounded by the Tethyan South Rifian corridor; which was the southern part of the Betic-Rifian basin (Choubert \& Faure-Muret, 1962; Cartes des Editions du Service Géologique du Maroc, 1992; Alvinerie et al., 1992; Bernini et al., 1992).

The locations of Pseudoniphargus longiflagellum (Fig. 6) are in the area covered by this Tortonian
Tethyan corridor. This channel was narrow in the Taza region (Michard, 1976; Alvinerie et al., 1992). Due to both the southward drift of the Rifian block and the northward drift of the African plate, as well as to the progressive regression of the sea during the late Tortonian period, a closure occurred in the narrowest area, which divided the channel in two gulfs. Therefore, the ancestral interstitial population of Pseudoniphargus, which lived in the coastal groundwater of the Tortonian channel, was divided in two populations, the evolution of which resulted in the two groups of the genus known in northern Morocco. $P$. longiflagellum clearly belongs to the ruffoi-longipes group which evolved in the eastern gulf (Coineau \& Boutin, 1996; Coineau et al., in press). Thereafter, the progressive regression of the Tethys, the deposits of detritic materials originating from the Rifian orogenesis, and the compression of the two plates resulted in the formation of numerous islands and many small isolated basins which functionned as small dead seas (Boutin, 1993), and finally in an anoxic environment that was sometimes supplied with marine water (Alvinerie et al., 1992). The eastern ancestral populations of Pseudoniphargus were also separated in several isolated populations that evolved through vicariance processes after the last regression at the end of the Tortonian period or at the beginning of the Messinian period, resulting in the evolution of several species such as $P$. ruffoi, $P$. longipes and $P$. longiflagellum. Other unknown species have been sampled in different parts of northern Morocco (Fakher el Abiari, 1999). More recent geological events might have also played a role in further vicariant processes and endemism of the group according to the present different hydrographic systems.

\section{Acknowledgements}

The investigations were supported by the "Convention d'échange C.N.R.-C.N.R.S. Franco-Marocaine", Action Intégrée InterUniversitaire n: 93/643, G.D.R. 88 Evolution des Microorganismes et Environnement, Contract ACC-SV n. 7 "Diversité Fonctionnelle et Evolution en Milieu Souterrain" and Project Pars $n^{\circ} 162 /$ Bìologie. We would express our gratitude to $M$. Knidirí, Recteur de l'Université de Marrakech, M. Mokhlisse, Doyen de la Facultè des Sciences de Marrakech, and A. Guille, Director of the Observatoire Océanologique de Banyuls, for their support of the subterranean hydrobiology studies. We are grateful to reviewers for their helpful comments. 


\section{References}

Alvinerie J, Antunes MT, Cahuzac B, Lauriat-Rage A, Montenat C, Pujol C. 1992. Synthetic data on the paleogeographic history of northeastern Atlantic and Betic-Rifian basin, during the Neogene (from Brittany, France, to Morocco). Palaeogeogr., Paleoclim., Palaeoecol. 95: 263-286.

Bernini M, Bocaletti M, EI Mokhtarh J, Gelat R, Iaccarino S, Moratti G, Papani G. 1992. Données stratigraphiques nouvelles sur le Miocène supérieur du Bassin de TazaGuercif (Maroc nord-oriental). Bull. Soc. Géol. France 163: 73-76.

Botosaneanu L, Holsinger R. 1991. Some aspects concerning the colonization of the subterranean realm - especially of subterranean waters: a response to Rouch \& Danielopol, 1987. Stygologia 6: 11-39.

Boulanouar M, Yacoubi M, Messouli M, Coineau N. 1995. Un nouveau Microcharon (Isopoda, Janiroidea) du Maroc. Origine et biogéographie historique. Contr. Zool. 65: 5364.

Boulanouar M, Yacoubi-Khebiza M, Boutin C, Coineau N. 1997. Un nouvel Isopode Mïcroparasellide (Crustacea Janiroidea) des eaux souterraines de la régìon péri-rifaine (Maroc). Bull. Soc. Hist. nat., Toulouse 133: 21-27.

Boutin C. 1993. Biogéographie historique des Crustacés Malacostracés stygobies du Maroc. Thèse Doct., Univ. Lyon I, 262 p.

Boutin C. 1994. Biogeography of the Metacrangonyctid amphipods in North Africa. Hydrobiologia 287: 49-64.

Boutin C, Coineau N. 1988. Pseudoniphargus maroccanus n. sp. (subterranean amphipod), the first representative of the genus in Morocco. Phylogenetic relationships and paleobiogeography, Crustaceana Suppl. 13: 1-19.

Boutin C, Coíneau N. 1990. "Regression Model", "Modèle biphase" d'évolution et origine des micro-organismes stygobìes interstitiels continentaux. Revue Micropaléont. 33: 303-322.

Boutin C, Coineau N. 1991. Instabilité des conditions environnementales et vitesse de l'évolution. L'exemple des microcrustacés souterrains d'origine marine dans les pays méditerranéens. Bull. Inst. Géol. Bassin d'Aquitaine 50: 63-69.

Boutin C, Messouli M. 1988. Metacrangonyx gineti n. sp. d'une source du Haut-Atlas marocain et la famille des Metacrangonyctídae $\mathbf{n}$. fam. (Crustacés Amphipodes stygobies). Vie Milieu 38: 67-84.

Boutin C, Messouli M, Coineau N. 1992. Phylogénie et biogéographie évolutive d'un groupe de Metacrangonyctidae, Crustacés Amphipodes stygobies du Maroc. II. Cladistíque et paléobiogéographie. Avec l'examen comparatíf de plusieurs logiciels de parcimonie. Stygologia 7: 159177.

Cartes des Editions du Service Géologique du Maroc. 1992. Rabat: Cartes des mouvements récents du Rif. Notes et Mếm. $\mathrm{n}^{\circ} 365$.

Choubert G, Faure-Muret A. 1962. Evolution du domaine atlantique marocain depuis les temps paléozoïques. In: Livre à la mémoire du Professeur Paul Fallot. Mém. hors série, Soc. Géol. France, Paris. I: 447-527.
Coineau N. 1971. Les Isopodes interstitiels documents sur leur écologie et leur biologie. Mém. Mus. Nat. Hist. Nat. NS A 64: 1-170.

Coineau N. 1986. Isopoda: Asellota: Janiroidea. In: Botosaneanu L, ed. Stygofauna mundi. Leiden: Brill/Backhuys, 465-472.

Coineau N. 1992. Bĭogéographǐe évolutive du Crustacé interstitiel Microcharon (Isopoda, Janiroidea) dans l'ouest du Bassin Médíterranéen. Bull. Inst. Océanogr. Monaco No. spécial 9: 101-114.

Coineau N. 1994. Evolutionary biogeography of the microparasellid isopod Microcharon (Crustacea) in the Mediterranean Basin. In: Biogeography of subterranean crustaceans: the effects of different scales. Summer Meeting of the Crustacean Society, Charleston, June 1992. Hydrobiologia 287: 79-96.

Coineau N, Boutin C. 1992. Biological processes in space and time. Colonization, evolution and speciation in interstitial stygobionts. In: Camacho AI, ed. The natural history of biospeleology. Madrid: Mus. Nac. Cienc. nat., CSIC ed., Monografias 7: 423-451.

Coineau N, Boutin C. 1996. Age and origin of the stygobiontic amphipod Pseudoniphargus (Crustacea) in Morocco, with the description of three new species. Boll. Mus. civ. Stor. nat. Verona 20: 503-520.

Coineau N, Boutin C, Fakher el Abiari A. in press. Origin, age and evolutionary rate of the microparasellid isopod Microcharon (Crustacea) from groundwater of the south-Rifian region (Morocco). Crustacean Issues (submitted).

Dahl E. 1958. Fresh and brackish water amphipods from the Azores and Madeira. Bolm. Mus. munic. Funchal 11: 525.

Delamare Deboutteville C. 1960. Bìologie des eaux souterraines littorales et continentales. Vie Milieu Suppl. 9: 1740.

Dercourt $J$ et al. 1985. Présentation de 9 cartes paléogéographiques au $1.20000000^{\mathrm{e}}$ s'étendant de 1'Atlantique au Pamir, pour la période du Lias à 1'Actuel. Bull. Soc. Géol. France 8: 637-652, avec un atlas de 9 cartes couleurs.

Dercourt J, Ricou E, Vrielynck B. (eds.) 1993. Atlas Tethys. Palaeoenvironmental maps. Paris: Gauthier-Villars, 1-307.

Fakher el Abiari A. 1999. Rôle des facteurs abiotiques dans la répartition de la faune aquatique souterraine: cas des Crustacés Péracarides Stygobies. Thèse Doct. Univ. Marrakech: 1-211.

Holsinger JR. 1986. Zoogeographic patterns of North American subterranean amphipod crustaceans. Crustacean Issues 4: 85-106.

Holsinger JR. 1994. Pattern and process in the biogeography of subterranean amphipods. In: Biogeography of subterranean crustaceans: the effects of different scales. Summer Meeting of the Crustacean Society, Charleston, June 1992. Hydrobiologia 287: 131-145.

Jaume D. 1991. Two new species of the amphipod genus Pseudoniphargus (Crustacea) from Cabrera (Balearic Islands). Stygologia 6: 177-189.

Karaman GS. 1978. Revision of the genus Pseudoniphargus 
Chevreux, 1901 (fam. Gammaridae), Boll. Mus. civ. Stor. nat. Verona 5: 239-258.

Karaman GS, Ruffo S. 1989. Tyrrhenogammarus sardous, new genus and species, with description of several new taxa of genus $P$ seudoniphargus Chevreux, 1901 from Sícily (Amphipoda, Gammaridea), Animalia 19: 161-192.

Messouli M. 1994. Evolution, phylogénie et biogéographie historique des Metacrangonyctidae, Crustacés Amphipodes stygobies du Nord de l'Afrique et des régions voisines. Thè̀se Doct. Etat, Univ. Marrakech: 1-309.

Míchard A. 1976. Eléments de géologie du Maroc. Notes Mém. Serv, géol. Maroc 252: 1-408.

Notenboom J. 1986. The species of the genus Pseudoniphargus Chevreux, 1901 (Amphipoda) from northern Spain. Bijdr. Dierk. 56: 75-122.

Notenboom J. 1987a. Species of the genus Pseudoniphargus Chevreux, 1901 (Amphipoda) from the Betic Cordillera of southern Spain. Bijdr. Dierk. 57: 87-150.

Notenboom J. 1987b. Lusitanian species of the amphipod Pseudoniphargus Chevreux, 1901 with a key to all known Iberian species. Bijdr, Dierk. 57: 191-206.

Notenboom J. 1988. Phylogenetic relationships and biogeography of the groundwater dwelling amphipod genus Pseudoniphargus (Crustacea), with emphasis on the Iberian species. Bijdr. Dierk. 58: 159-204.

Notenboom J. 1991. Marine regressions and the evolution of ground-water dwelling amphipods (Crustacea). $J$. Biogeography 18: 437-454.

Pretus JL. 1988. A new stygobiont amphipod, Pseudoniphargus mercadali n. sp., from the island of Minorca (Balearic archipelago). Stygologia 4: 229-241.

Pretus JL. 1990. Three new species of the genus Pseudoniphargus (Crustacea: Amphipoda) in Balearic groundwaters. Stygologia 5: 101-118.

Platnik HJ, Nelson G. 1978. A method of analysis for historical biogeography. Syst. Zool. 27: 1-16.

Rögl F, Steininger FF. 1984. Neogene Paratethys, Mediterranean and Indo-Pacific seaways. Implications for the paleobiogeography of marine and terrestrial biotas. In: Brenchley P, ed. Fossils and climate. New York: John Wiley: 171-200.

Sánchez E. 1990. First records of the genus Pseudoniphargus
(Amphipoda) from Gran Canaria, with description of a new species. Stygofauna of the Canary Islands, 17. Bijdr. Dierk. 59: 229-238.

Sánchez E. 1991. Stygofauna of the Canary Islands, 18. New records of Pseudoniphargus (Crustacea, Amphipoda) from ground waters of Tenerife and Hierro, with description of new species. Stygologia 6: 53-64.

Steininger FR, Rögl F. 1985. Paleogeography and palinspastic reconstruction of the Neogene of the Mediterranean and Paratethys. In: Dixon JE, Roberston AHF, eds. The Geological Evolution of the Eastern Mediterranean. Special publ. Geolog. Soc., 17, Blackwell Sci. Publ.* 659-668.

Steininger FF, Senes J, Kleeman K, Rögl F. 1985. Neogene of the Mediterranean Tethys and Paratethys. Stratigraphic correlation tables and sediment distribution maps. Vol 1: 189 p., 10 colored maps. Inx PICG UNESCO $n^{\circ} 25$ "Stratigraphic correlation Tethys-Paratethys Neogene 1974-1983". Institute of Paleontology, Univ. Wien.

Stock JH. 1977. Microparasellidae (Isopoda Asellota) from Bonaire. Stud. Fauna Curaçao 51: 69-91.

Stock JH. 1980. Regression model evolution as exemplified by the genus Pseudoniphargus (Amphipoda). Bijdr. Dierk. 50: 105-144.

Stock JH. 1988. Stygofauna of the Canary Islands, 9. The amphipod genus Pseudoniphargus (Crustacea) in the Canary Islands. Bijdr. Dierk. 58: 47-78.

Stock JH, Abreu AD. 1992. Three new species of Pseudoniphargus (Crustacea: Amphipoda) from the Madeira archipelago. Bolm. Mus. munic. Funchal 44: 131-155.

Stock JH, Holsinger JR, Sket B, Iliffe TM. 1986. Two new species of Pseudoniphargus (Amphipoda), in Bermudian groundwaters. Zoologica Scr. 15: 237-249.

Wägele JW. 1990. Aspects of the evolution and biogeography of stygobiontic Isopoda (Crustacea: Peracarida). Bijdr. Dierk. 60: 145-150.

Yacoubi-Khebiza M, Boulanouar M, Coineau N. 1997. Un nouveau Microparasellidae (Crustacé Isopode) du HautAtlas; aspects phylogénétiques et biogéographiques. Contr. Zool. 66: 227-234.

Received: 30 November 1998 